\title{
Diaspora and Syncretism: Marriage Rites in Yorùbá Homeland and Abroad
}

\author{
Olanike Lawore \\ Department of English \\ Louisiana State University \\ olawor1@lsu.edu
}

\begin{abstract}
The marriage institution is as old as the human race and is valued for companionship and procreation. The Yorùbá race accords great importance to this institution and has a distinctive manner of contracting its nuptials which underscores the sacredness it attaches to marriage. The importance attached to this union is evident in parents' preparation even before the girl-child is born, including contracting a marriage proposal on her behalf. This marks the beginning of a long process that will eventually culminate in future marriage. As Yorùbá people are found all over the globe, the marital rites are transferred from the original soil to the diaspora, the result of which is the syncretic practices that are associated with marital practices abroad. This essay therefore engages in a comparative exercise, identifying marital rites in the diaspora that have maintained close ties with homeland and those that have diverged from them.
\end{abstract}

\section{Introduction - The Genesis}

Marriage rites are some of the most cardinal customs of the Yorùbá people. Apart from the obvious reason of companionship, marriage is especially treasured among the Yorùbá people for the important reason of procreation. As children prove one of the most motivating factors for marriage in this culture, the people strongly believe in taking proper steps to establish a good home within which such a sacred task of parenting might be carried out. Well-trained and responsible children (omọlúàbí) are a source of pride to any family and an irrefutable proof of a sound, fruitful and thoughtful 
marital union. Recognizing this fact is crucial to understanding the purpose of the several processes involved before matrimony is eventually consummated. These processes, however, have altered with time, due to the effects of western education, and migration. Migration plays a major role in the alteration of some of the customs of these people. The Yorùbá people are generally known to be explorers, (a concept captured in the mythology of the creation of Yorùbáland), migration being a very common practice among them. This factor single-handedly explains the roots of the syncretic practices as are inherent in the performance of certain rites in this culture. Even though their primary domain, considered home lies in the Southwestern region of Nigeria, the Yoruba people are found in all thirty-six states of the country. The focus of this paper, therefore, is centered on exploring the Yorùbá marital rites carried out both within and outside the heartland of the Yorùbáland, the purpose of which is to gauge the level of retention as well as divergence in the resultant practices.

\section{Home States}

The Yorùbá people are the primary inhabitants of Southwestern states of Nigeria. It is worth mentioning that the city of Ilé-Ifẹ is symbolic to the Yorùbá people in two ways. First, in Yorùbá mythology, the world is believed to have begun in Ilé-Ifẹ́; it is also believed to be an ancient city from where all the Yorùbá people originate (Ladele and Mustapha 11). It therefore holds both a historical and spiritual significance. Because of the command issuing from Òdùduwà, the founding father of Yorùbáland, to his seven children to spread and extend their territory, Ilé-Ifẹ gave way to other kingdoms that are now recognized as indigenous Yorùbá states in Nigeria. Yorùbá people have since traversed beyond their home states into other states in Nigeria, and indeed moved further into other parts of the world with their cultures following closely. The result of the language and culture contacts emanating from these sojourns and migrations, is that it introduces some modifications in a number of Yorùbá customs. This study is an attempt to investigate how much of these cultures, in relation to marriage, are still retained in the diaspora. It will provide answers to questions such as: Are the marriage rites or practices the same in diaspora as are in the home country, Nigeria? What are the alterations or modifications discernible, if any? To what degree do they change if they do?

\section{The Diaspora}

The concept of the diaspora was, from its inception, confined to capturing the involuntary dispersion of the Jewish population from their native land dating to 586 BC. AsToyin Falola and Matt Childs oberve, it was not until 
the twentieth century that there emerged a finally accepted legitimization of diaspora for history studies that, along with African history, have been the most marginalized fields in the historical profession (Childs \& Falola 1). In this wise, the place and role of Africans and their descendants in the global space begin to be the preoccupation of many treatises. The term diaspora is normally used within the social confines of home-community versus the for-

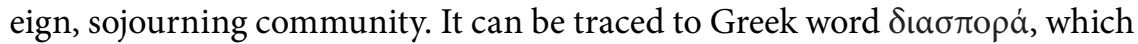
means to scatter, to sow widely, to expand (Cohen 507; Olaniyi 2). Olaniyi is of the view that this term is used to depict a community, "which has a history of migration, possess[es] distinctive cultural practices that distinguish it from the host community" while still maintaining cultural ties with the homeland (2). The seminal work of W.E.B. Du Bois and Carter Woodson formed the ground-breaking study for the discourse on African diaspora which later critics such as Melville Herskovits built on, by investigating how the survival of Africans in diaspora have shaped religious and secular life globally. The Yorùbá diaspora, as far as Olaniyi is concerned, "includes people who have experienced migration and those born in migration and brought up in new community of settlement" and whose maintained cultural ties "survived, transformed, and remained relevant even when members of the diaspora have not lived in the original homeland" (Olaniyi 5).

In essence, diaspora communities operate within a complex dynamic, the outcome of which is a hybrid culture, although aligned in worldview with its community of origin; yet not indifferent to its host community. This invariably explains the syncretic nature of many of the Yorùbá culture and practices in the diaspora. The term Yorùbá diaspora is, therefore, used to refer to people of Yorùbá descent who, although live outside the shores of the Yorùbá homeland, maintain sociocultural linkages with the homeland or continue to maintain their Yorùbá identity (Olaniyi 4). J.S. Eades identifies four different kinds of migration among the Yorùbá, which culminated in the formation of diasporic Yorùbá communities (63-87). These range from unskilled labor-migrants of the colonial period on the look-out for jobs on cocoa farms in bigger towns to migrant-farmers hunting for suitable land for planting cocoa, long-distance migrant traders, younger educated migrants to urban centers which led to the expansion of education in the 1950s (Ibid.). Eades also stresses the influence of relationships such as kinship in channeling migration as people travel to join their relatives in larger towns to secure better stations. By this, material and information exchange become a natural outcome of these expeditions. 


\section{Syncretism}

In his treatment of syncretism, Brian Joyner in the National Service Park project fixes his exploratory lens on the American history as his field of study, asserting that the origins of the United States were founded upon the influx of immigrants. He posits that the populace was derived from peoples from nations all across the globe. He goes further to establish that:

hundreds of indigenous American Indian tribes were already present in the sixteenth century when several European groups and a sizable number of Africans began to arrive. Later, groups from Asia, the Middle East, Central and South America, and many other corners of the globe arrived on the North American continent and made it their home. This phenomenon continues today, where new Americans arrive in the United States, adapt their cultures to the environment of the New World, and transform the national culture of the United States. (Joyner 1-64)

He notes also that due to transatlantic slave trade, of all the ethnicities that landed on the spheres now known as the United States, West and Central African emigrants comprised one of the largest groups to arrive during the colonial era. The 17th and 18th century ship ledgers and insurance rolls teem with names of the various West and Central African ethnic groups: Wolof, Fon, Yorùbá, Igbo, Fang, Mandinka, and Kongo, to name a few. African peoples were found throughout the American colonies, from Maine to Florida, and Mexico to Canada. By 1830, the U.S. census indicates that 2.3 million of the 12.8 million people in the United States were of African descent (Ibid. 1). It is noteworthy that Eades, Olaniyi, and Joyner attempt the treatment of diaspora in very useful yet different ways, which are nonetheless functional for the purposes of this study. While Eades and Olaniyi envision it as a concept within intra-national domanis, Joyner views it from the perspective of the global; in this way, both create an interesting mix. This invariably means that while the above-mentioned critics assess diaspora as a translocal concept, Joyner situates it within even broader cosmopolitan contexts. In this way, we are provided with two forms of diaspora. For Eades and Olaniyi, diaspora can be said to be in operation, when native speakers of a language, although live within their country, have moved out of the locale of their home-states. In essence, a Yorùbá man or woman who moves away from the native states of Nigeria into other regions of the country where other cultures and languages are in practice, is a diasporan. Joyner, however, views it from an international, cross-continental perspective, which for the purpose of this study, proves useful, in that it allows us to envision different forms of diaspora and how diasporic experiences shape cultures. In addition, it allows for the juxtaposition 
of Yorùbá marriage rites and practices in homelands and their transmutations in the different forms of diaspora.

With the transportation of Yorùbá customs and marriage rites from homelands to the diaspora, syncretic Yorùbá practices were the result, creating a blend of native Yorùbá customs and those of host communities. However, in spite of the different names ascribed to the Yorùbá people globally, such as Nago in Brazil, Lucumi in Cuba, Aku in Sierra Leone, Nagot or Anago in French Dahomey and Togo, they are often singled out as a distinct cultural group and linked to their homeland roots in Nigeria. This is interesting because while there is an undeniable shift in the lexicon as well as in the expression of cultural and religious practices of the Yorùbá people in diaspora, they still have an irrefutable link to the homeland.

\section{Yorùbá Diaspora in Northern Nigeria}

The formation of Yorùbá diaspora in northern Nigeria can be situated within the British colonial conquest and enterprise. Migration was largely driven by colonial labor policies; meagre commercial opportunities available for Africans, and deprivations during economic crises encouraged this practice. Thus, economic pursuits produced a set of Yorùbá craftsmen, laborers, and traders in different cities where they sought better economic prospects (Olaniyi 12). Olaniyi contextualizes Yorùbá diaspora in northern Nigeria within the historical context of Yorubá commerce vis-a-vis the colonial enterprise. With the cross-cultural marriages between some Yorùbá and other ethnic groups in the north (such as Hausa, Fulani, Kanuri, etc.), Yorùbá marriage practices became altered owing to this culture contact. Also, some Yorùbá migrants, leaving behind their traditional religious beliefs embraced the non-Yorùbá cultural and religious practices of their host communities. Commenting on the intermarriage unions between Yorùbá people and the Northerners, Isa Hashim posits that the willingness on the part of the Hausa, most especially, to contract these unions was mostly engineered by the fact that since a greater part of the Yorùbá migrants were Muslims, according to Islamic custom, they were considered as brothers and sisters to the Hausa people (Hashim in interview 2003). This probably explains why many Yorùbá people have been assimilated into Hausa culture. Another reason cited by Hashim centers on the vibrant and entrepreneurial nature of these Yorùbá migrants who brought their admirable skills along with them. Thirdly and perhaps most significantly, the Yorùbá people share the same myth of origin with the Kanuri people of the northeastern part of Nigeria (Ibid.). This point has however been contested by critics. It would seem that the import of this 
argument is that the Yoruba diasporans in the north and the Northerners share semblances with which they can relate.

Saburi Biobaku argues, however, that to properly articulate the discourse on Yorùbá migration is not to begin from Nigeria; it is rather to look at the history of the Yorùbá people itself. He argues that the Yorùbá people are not indigenous to Nigeria. They were immigrants from a region where they came under the influences of ancient Egypt, Etruscans, and Jews (Biobaku 63-64). Their original home, he contends, must have been in the near East where they acquired Egyptian influences. In coming under Arab subjugation, their migration was connected with Arab movements which occurred in waves. When the Yorùbá migrant group arrived in the place now known as Northern Nigeria, they established a settlement at Idah, where they were known as Igara. The major wave, however, occurred in the now Yorùbáland in Ekiti, from where they went on to form other Yorùbá settlements, such as the Idoko (Biobaku 64). These seemingly contradictory positions of Olaniyi and Biobaku, nonetheless reveal the recurring theme of migration and cultural influences. The role of migration in the syncretism inherent in many Yorùbá cultural practices is therefore quite significant indeed.

However, the question that comes to mind at this point is: To what extent does this perceived close relationship go in influencing the native cultural practices of the Yorùbá people? Although it may be surmised that the Yorùbá people from the southwestern and the northern host states of Nigeria share certain religious and cultural values, (with these Yorùbá diasporans acquiring new ones from their host communities) this does not in any way imply a blurring of cultural boundaries as the reverse is actually the case. Indeed, the provision of the Nigerian 1999 constitution, which places emphasis on places of origin and indigeneity rather than residency (Olaniyi 8), complicates this relationship dynamic, in that diasporans are forced to maintain cultural affiliations with their native states of origin. The result of this is that when cross-cultural ceremonies such as weddings, funerals, or naming ceremonies come up, there is usually a blending of both cultures resulting in the syncretic cultural practices.

\section{Yorùbá Marriage Processes in the Homeland}

Yorùbá parents in the heartland of Yorùbáland envision the institution of marriage to be so crucial that they consider it their sole responsibility to guide their children in choosing their future spouses. In some rare cases, shortly after the female child is born, she may be betrothed to a future-husband. There is usually some agreement between parents of little boys and those of baby-girls in contracting the future union of their children. Parents base their 
choice on what they consider key factors: their relationship with their prospective in-laws, the level of intimacy between the families, the integrity of the intended in-laws, the family's historical background and reputation as well as their ancestry or lineage. This responsibility rests on the parents of both parties; both on the boy's parents who have to make the proposal, and the baby-girl's parents, whose primary task is either to accept or decline such a proposal. Background checks on both ends are considered crucial before any agreement can be reached concerning such a grave matter, as they considered it. Much of these background checks are aimed at eliminating families who have a history of a stigmatizing malady, such as leprosy, insanity, witchcraft or any diabolical trends or tendencies which they believe will not only obstruct the new couple's growth as a family but also cause their prospective grandchildren to be initiated into the diabolic cult. This is a worrying possibility which the intending families seek to obviate by carrying out some background researches on one another. Ultimately, these checks are meant, among other reasons, to measure the future success of their children's marriage.

This is not all that there is to the marriage selection process however, because all of the above precautions, no matter how successful, must go through the oracle's (Ifá's) screening to know if both parties' destinies (orí) match and if their elẹdàa (another name for orí) can successfully cohabit within the confines of marriage. The oracle sometimes warns against certain otherwise suitable matches by predicting untold woe and doom in future for the intending couples if they went ahead to marry. Once Ifá forecasts a clear and bright future for an intending couple, each of the families is obliged to keep their word to this contract and the parents of the girl-child may not give her to another family.

\section{Preparation for Courtship}

Once the girl reaches the age of about fifteen, and the prospective suitor, about eighteen, courtship officially begins. It is important to note that before both attain these ages considered the ages of maturity (bàlágà) for both genders, they would have been aware of their engagement to each other. Indeed, they grow up with this knowledge which soon becomes a part of them, as their parents' guide them through the appropriate modes of conduct within the family as well as in the community at large. The bride-to-be would be tutored by her mother and the other older women in the art of home-keeping. The task of preparing the groom-to-be for the responsibilities of a husband rests on the father as well as other father-figures in the household. 


\section{Courtship}

Courtship commences with the aid of a chaperone or middle person (known as alárinà) who formally introduces the couple to each other and oversees their conduct and comportment in an unobtrusive manner. As the bride-to-be is usually painfully shy in the beginning, it is the duty of the alárinà not only to formally introduce the young intending couple to each other but to also make the business as smooth as possible and to ease the discomfort of the bride, helping her come to terms with meeting her husband-to-be more easily. However, once the couple is comfortable enough in each other's company, the alárinà takes his or her leave of them, which is the source of the proverb that addresses the subject: bí oko bá m'ojú aya tán, alarinà á yẹbá - meaning: when the groom becomes sufficiently familiar with his bride, the chaperone departs. The alárinà is usually someone who is familiar with the bride-to-be and around whom the bride-to-be is comfortable. This person is either male or female; most are female, however. In line with the nature of the responsibilities attached to the alárinà, he/she must be: mature, truthful, a person of moral and social integrity (ọmọiúabi), and familiar with the rubrics of courtship so as to offer advice to the couple when needed.

\section{Introduction (Mọ-mí-n-mọ ọ́)}

This is a crucial as well as a giant step leading to the nuptials. It is a formal introduction ceremony that takes place in the home of the bride's parents. It signifies a formal meeting between the families of the bride and the groom. It is usually a strictly family affair where the groom's parents and family formally request the consent of the bride's parents in giving them their daughter for marriage. The bride and groom are present at this occasion. The immediate family members such as the siblings, close relatives in persons of aunties and uncles are also required to be present. In many modern day Yorùbá communities, the introduction has ceased to be a family affair. It is usually announced to friends and well-wishers and celebrated in an elaborate style. The nature of family introductions, nowadays, is dependent on family choice and financial capacity.

\section{Yoruba Marriage Processes in Diaspora}

While Yorùbá parents in the diaspora neither betroth their children nor impose on them regarding whom to marry, many parents who are devoted to their indigenous cultures are nonetheless concerned when the time comes for their children to choose spouses. This is especially so for parents who hope that their grandchildren would be grafted into their culture or at least be brought up by parents from the same tribe who can then inculcate in them 
the character of omọluábí. Some parents advise their children to look out for potential spouses from among people of their own tribes and culture when they decide to settle down to matrimony. Yet, some parents are not overly concerned about the cultural orientation of their children's prospective spouses and are only content that they observe certain rites in the wedding that are symbolic of their Yorùbá cultural roots.

Family introduction in the diaspora, although not as elaborate as in homeland, is very important to the Yorùbá people, whose belief is that one must meet with one's in-laws before one gives out a daughter or accept a daughterin-law, whether at home or abroad.

\section{Idì in Yorùbá Homeland}

This refers to edible things that would be sent to the bride's parents. This was a yearly practice that involved the groom's father taking these edible items to his son's future mother-in-law. This period was usually targeted at the time of harvest and so farm-produce constituted the bulk of these gifts. This gift-presentation would have commenced from the time of engagement. The purpose of this is to show the bride's people that they not only are aware of their responsibility (mo ètọ') but also to prove that their daughter is in safe hands. Before presenting these gifts (idi), the groom's parents would have sent to the bride's parents to indicate when they would be visiting. The women of the house from the groom's family were usually the presenters of these gifts from the groom's father to the bride's mother. In other families and communities, the duty of receiving the gifts rested on the chaperone (alárinà) who went to collect these gifts and presented them to the bride's mother (Aromolaran and Mustapha 12).

Even though these gifts are presented to the bride's mother, in a polygamous setting, she must take them to the eldest wife or the oldest female in the house, who in turn, shares them among the members of the bride's family. In practice, these gifts are in fact for the entire household of the bride's family. The recipients of these gifts would receive them joyfully and offer words of prayer for the success of their daughter's marriage. This yearly practice engenders love and unity among all the wives in the family who take delight in calling the bride their daughter (Aromolaran and Mustapha 11).

\section{Comparison: Idì in Modern Day Yorùbáland and the Diaspora}

It seems as though this yearly practice is predominantly confined to native Yorùbá land, and even then, it appears to have altered considerably with time. This is not to say that modern day Yorùbá in-laws do not present gifts to the bride's mother, for indeed they do. However, it takes on another form which 
ceases to be practiced as an act of obligation but more as an act of free- and good-will, on the part of the groom's family. This act then finds its natural place within family events such as the formal introduction of both the families, and at the engagement ceremony of the intending couple. However, the yearly presentation of gifts as a prescription of $i d i$ by prospective in-laws to the bride's mother as an ethical norm, is an ancient Yorùbá custom that has died a natural death for several reasons we shall discuss later.

It should be noted, however, that certain families send gifts to their prospective in-laws on a yearly basis, before and after the marriage of their children. This is in no way obligatory, as the ancient Yoruba culture obligated it. The same principle applies to the Yorùbá in diaspora.

\section{òwẹ̀}

This is a form of service rendered to the bride's father. The bride's father would request that his prospective son-in-law help out with some tasks on his farm, an obligation the groom is usually happy to meet, with the aid of his friends. At important seasons, when extra help is needed, the bride's father is usually happy to make use of this privilege. This form of dowry is particularly useful to fathers whose children are mainly female. As farming is a vocation predominantly within the domain of the male-gender in the Yorùbá community, although women owned and managed farms, this sort of help is invaluable to a bride's father.

It is obvious that this practice would die a natural death in a modern-day Yorùbá community, where the agrarian culture is not as popular and where formal Western education has taken roots. For obvious reasons, similar principles apply in the diaspora, where this aspect of the culture is silenced.

\section{Dowry (Owó orí)}

Dowry is both a crucial as well as a symbolic aspect of the marital rites of this culture and it is paid in the form of money by the groom's family to the family of the bride. The bride's family quotes an amount that the groom's family is required to pay. This amount is less consequential than what it represents: a token of value placed on the head (ori) of the bride, a symbol of a priceless exchange between obliging and consenting parties. The bride's parents, the immediate and the extended family of the bride, and the bride-to-be herself all have a share in this money, as far as the custom goes. The purpose of this is to seal and bind the prospective union as one that has the co-operation and support of all members of the family, including distant relatives. The mother's share is called iyá-gbọ (meaning: mother is informed), the father's share, on the other hand, is called bàbá-gbà (father consents). The precise amount to be paid as dowry varies from community to community, family to 
family and the same principle applies to families in diaspora. A Yorùbá proverb captures this understanding: báyií ni à ń șe nílée wa, èèwo ibòmíràn ni (meaning: a customary practice in one family is taboo in another). It is, however, worth noting that in spite of this lack of uniformity in the amount of the dowry the bridegroom's family is required to pay, the Yorùbá people are widely reputed among the other cultures in the home country, Nigeria to request the least amount of dowry. It is a common practice among the Yorùbá people not to impose exorbitant amounts as dowry, an action informed by the belief that their daughters are not objects to be sold. This is in direct variance with other tribes in Nigeria, such as the Mbaise people of Imo state, the Ikwerre people of Rivers state, the Ngwa and the Nkpa people of Abia state, Efik people of Cross Rivers state where dowries are considered extremely high, because as some of these tribes claim, the groom's family should be responsible for what it took to raise and educate the bride; this invariably means that the more educated the bride is, the more expensive the dowry.

Owó orí in diaspora is as indispensable as it is in Yorùbá heartlands. This aspect is quite significant and forms one of the cardinal bedrocks of any would-be Yorùbá marriage. Couples who marry abroad are generally known to send home the dowry to the bride's family living in the homeland. Without it, Yorùbá marriages are not believed to have been sealed. Indeed, such marriages are not recognized, even when they seem to have fulfilled other rites. The couples within such wedlock are merely considered to be cohabiting, an act considered shameful. It is important to reiterate that the significance of the dowry is not in any way tied to the amount, for it is in many cases quite meagre. It is rather significant for the symbol that it holds: the groom and his family have properly sought and received the permission to marry the bride and the payment provides a proof of acknowledgement of the bride's value and virtue. Many modern day Yorùbá natives who marry in the church or mosque also fulfil this Yorùbá custom requirement during the introduction or the engagement phase of their union.

\section{Cash Gift to Friends (Owó-Ẹgbẹ)}

Sometimes, a bride could specially request some money from her husband-to-be in order to entertain her friends when they go to outings, such as friends' dance (ijó-egbẹ́) or ijó-ọún (end-of-year dance). The groom must be present at these outings in order to honor his wife-to-be with money (náwó) while she dances, and so distinguish her from amongst others. This practice is not practiced as a norm in modern day Yorùbá states or in diaspora. 


\section{Yorùbá Traditional Wedding}

In his "Semiotics and Language Interlarding in Yorùbá Traditional Bilingual Discourse," Adebukunola Atolagbe identifies participants of traditional wedding, according to their order of importance:

i. The bride and the groom (ii) Parents of the bride and parents of the groom, or any close aunt or uncle representing any of the parents who may be deceased. (iii) Siblings of the bride and groom; grandparents of the bride and groom; relations such as cousins, aunts, uncles, nephews, nieces and household members. (iv) Friends of the bride and groom; colleagues, neighbors and all informed acquaintances. (v) All wives married into that family and all in-laws of the family. (vi) Alága İjókòó (Sitting chairperson and spokeswoman for the bride's family; rarely a spokesman) and -- Alága İdúró (that is, standing chairperson and spokesperson for the groom's family. (vii) Any priest or religious/traditional representative who comes as one of the categories of participants mentioned earlier and doubles partly as an officiating minister. Priests are usually not invited in the capacity of officiating ministers at such a wedding, but they are usually called upon to perform such rites along the line. (Atolagbe 159)

Guests all turn out in traditional outfits: a blouse, matching wrapper and head- gear with matching pair of shoes for the females; a top, matching pair of trousers, elaborate ceremonial gown (agbádá; not obligatory but could depict status), and a pair of shoes for the males. On most occasions, the respective families of the bride's and groom's wear distinctive uniform materials, known as ànkóo (however, sown to individual tastes and style) to indicate the family to which the members belong. The wedding is in general hosted and sponsored by the bride's family, in their house or any other designated venue. Sometimes however, the groom's family might decide to assist in sponsoring the wedding financially if they are well-off and particularly want to show this to the bride's family who may not be as wealthy as they are (Atolagbe 159-160). The agenda of the traditional wedding ceremony includes the following: dowry (owó orí), gifts for the bride (ẹrù iyàwò), and gifts for the inlaw (ẹrù àna)

Besides these, the groom's family is presented a list by the bride's family which contains the things they must procure for the wedding, such as: salt, honey, sugar, sugarcane, a variety of fruits, yam, bitter kola, kolanut, cooking wares, and such likes. Many of these items are symbolic and are used to pray (súre) for the couple. Honey and sugar imply a pleasurable life. Salt signifies a satisfactory life; alligator pepper (ataare), peppered cornmeal (àádùn), bitter 
kola (orógbó) and kolanut (obi), connote long life and would be used together with the other items to pray for the couple.

Alága Ijókòo (Sitting MC usually female, rarely male) stands in for the bride's family and co-ordinates the ceremony. She introduces the bride's and the groom's families; she also introduces the groom to the bride's family, making the groom and his friends to entreat them for their daughter's hand by prostrating before them. Alága Ijókòó finally ushers in the bride and lets the second MC take over. Alága İdúró (Standing MC, he/she stands in for the groom's family who are coming to beg for the wife) takes over and directs the proceedings of the second part. She introduces the bride to the groom's family. She later directs the payment of the bride price, while also accepting the items brought by the groom's family on behalf of the bride's family. Each of the alága is usually clad in the same attire (aṣo ẹbi) as the side of the family they are representing.

\section{Bridal Song/Chant (Ẹkún İyàwó)}

The bride's chant is not a general practice in all Yorùbá lands as it is mostly a practice associated with the Òyọ people of Nigeria. For those who observe this practice, it is one of the most important aspects of the wedding and usually emotionally laden. At the close of the wedding ceremony, as noted by Olalere Raji and Rasaq Ajadi, when the bride goes before the male and female elders of her family to obtain their blessing, it is an emotional experience for her as she prepares to leave the home and household she has always known for a totally new one. At the end of these prayers, she turns to her mother for prayer as well and it is on this note that she renders her heart-breaking song with which participants also empathize (Raji and Ajadi 148).

\section{Yorùbá Traditional Wedding in Modern Times}

The above practice is still relevant in modern day Yorùbá wedding. However, there are additional practices that present day traditional weddings would include, particularly if they are educated. One of such innovations is the introduction of the letter of proposal from the groom's family as well as the letter of acceptance from the bride's family which is read aloud by the representative of each family.

\section{Marriage Consummation}

Brides were expected to be found virgins at the time of marriage. To be found otherwise is considered a disgrace, not only to the woman in question but to her entire family. The groom's family feel short-changed, when this happens to be the case. To ascertain the innocence and virtue of the woman, 
the family of the groom escort the new couple to their new home, taking their position outside this new home, waiting for the good news as the groom goes in into his new wife. It is good news, when the husband emerges from the house with a white piece of cloth stained with blood, a proof of his wife's $f$ delity. It is very bad news, on the other hand, when there are no bloodstains to show as proof of her virginity. When a woman is confirmed a virgin, it is considered a thing of great honor, pride and joy for the bride's family. There is a separate acknowledgement and celebration for this. Early the following morning, the groom's family would send some people to go to thank the bride's parents for presenting them a "wholesome" gift in the person of the bride. They would offer a number of gifts, including a full gourd of wine, symbolic of the bride's virtue. It is a condensed way of praising the bride's family for preserving their daughter and remaining faithful to the pledge of marital union. Her father calls a party and celebrates with his friends. The groom in like manner presents his wife with a monetary gift to appreciate her faithfulness.

When the reverse is the case, the woman is considered as a disgrace not only to her family but to womanhood. It is believed that she is bereft of honor. Consequently, the groom's people send a disgraceful message to her family, asking them to come take their daughter who was weighed but was found to be grossly wanting. They also present the father with a half gourd of palm wine to scornfully imply that their daughter is deficient where it mostly matters. The bride's father in turn usually gives the gourd to her mother, claiming that since she is her mother, she must know about the unsteady ways of her daughter. It is often a tragic occasion for the bride's family at this instance, as the family name is considered soiled. Occasions such as this often serve as reminders to betrothed girls whose parents would often admonish to keep their virginity to save the whole family any disgrace. It is a dreaded incident for the brides' families of this period.

In modern times, far less emphasis is paid to the sexual status of the bride in terms of her virginity, although parents of the groom stress the importance of attributes that their prospective daughters-in-law should possess, ranging from being responsible, respectable and well-behaved (omolúàbí). The proof of virginity custom is a practice that is now obsolete in today's native Yorùbáland, even if some parents still counsel their children on the importance of making sound and informed choice and to not pick a promiscuous woman as wife. She is to be a woman of sound moral character. The same principle obtains in the diaspora and it ultimately boils down to individual and family values. Ultimately, the choice of who to marry rests on the concerned parties, namely the man and the woman. 


\section{Modern Times and Changes}

Several cultural changes, ranging from mild to radical, have occurred, even in native Yorùbá communities. While Yorùbá parents still expect and in fact, demand some form of introduction to their prospective son or daughter-inlaw, they no longer choose or impose on their children on whom they should marry. This is not to say, however, that some families do not nudge their children in the direction of persons that they consider suitable matches for them; for indeed they sometimes do, and this is many times the source of variance between children and their parents. There are cases where parents refuse to give their blessings to unions they do not agree with, even in modern times. However, this much must be said which is that, unlike at earlier times when children could hardly refuse their parents' choices, as marriage was considered a matter of grave importance to be sorted out only between families, and not between the individuals involved, the same cannot be said of children in modern times. With this decision reached long before the children of both parties are old enough to know what had been happening, they simply grew in the knowledge that they already had fiancés and fiancées and ultimately followed through the marital process.

Although the custom of pre-arranged marriages is no longer in practice, some parents still wield some power in influencing their children's choices. They could threaten to withdraw from playing any role in the wedding if they consider their children's choices unsuitable. Some insist on specific tribes or nationalities, family backgrounds and such likes that their prospective son or daughter-in-law must come from. Needless to say, this has often been the source of conflicts in many homes. In Yorùbá custom, parental participation is considered crucial and indeed indispensable to tying marital knots. Parents play the roles of both the giving away and the receiving of daughters in marriage, depending on the gender of their children. Because in traditional Yorùbá contexts, parental blessings are considered the backbone of any would-be successful marital union, children are usually in a dilemma in these occasions. Some children patiently persuade their parents on the wisdom of their choice, others elicit the help of other family members or relatives to plead their cause; a few, however, go ahead with their weddings without their parents' involvement. The latter action is often considered extreme and a source of potential marital failure. Despite the fact that parents still play an important role in their children's marital unions even in modern times, it is clear that the level of power dynamics has changed considerably. More so, some parents now adopt a hands-off approach regarding their children's marital choices; obviously, this is largely dependent on people's outlook on life and the impact of their diasporic experience and its role in crafting inter-sectional 
identities. The summary of this is that although the role and place of parental intervention in their children's marriages have altered considerably, their involvement is still considered crucial in native Yorùbá settings.

\section{Conclusion}

The long process between the time a child is betrothed and the time the wedding is done underscores the importance the Yorùbá race attaches to the institution of marriage. The involvement of the immediate family, extended family and the community at large, further reinforces the value to which marriage is accorded in this culture. The Yorùbá people, irrespective of where they are found - home or abroad - have their distinctiveness, as far as marriage rites are concerned. Certainly, there are variations in the expressions of those customs that mark out the Yorùbá people from the rest of the world due to reasons such as migration and separation of significant number of Yorùbá people from the soil of their nativity, the impact of culture contacts, and the role of modernization. The syncretic nature, notwithstanding, many of the marital rites identified in this study, have betrayed sentiments deeply rooted in the heartland, while other customs have surprisingly remained unchanged.

\section{Bibliography}

Atolagbe, Adebukunola. "Semiotics and Language Interlarding in Yorùbá Traditional Wedding Bilingual Discourse." Journal of English and Literature. 3.7, November (2012): 158-165. Web. DOI: 10.5897/IJEL12.054

Aromolaran, Adebisi and Oyebamiji Mustapha. Akomolede Ijinle Yorùbá. Ibadan (Nigeria): Macmillan Press. 1976.

Avery, Nicole Volta. "Kiss of Culture, Ethnic Wedding Traditions," About Time Magazine, August 1996.

Biobaku, Saburi. “The Pattern of Yorùbá History.” African South. 2. 2, (1958): 63-67.

Cohen, R. "Diasporas and the Nation State: From Victims to Challenges." International Affairs. 72, (1996): 22-41.

Cole Harriette. Jumping the Bloom: The African American Wedding Planner. New York: Henry Holt and Co., $2^{\text {nd }}$ Edition, 2004.

Du Bois, W.E.B. The Negro. New York: Holt. 1915.

Eades, J.S., 1980, The Yorùbá Today. Cambridge: University of Cambridge Press, 1980.

Edevbie, Onoawarie. “A Text for Isoko-Urhobo Traditional Marriage." In

Ekeh, Peter P. (ed.). Studies in Urhobo Culture. Lagos/Buffalo, New York: Urhobo Historical Society. 2005.

Hashim, Isa. Interview by Rasheed Olaniyi.Department of Political Science 
Bayero University, Kanoon 10th December 2003 at Maizube Farm, Minna. Herskovits, Melville. The Myth of the Negro Past. Beacon Press Books. 1941.

Joyner, Brian. "African Reflections on the American Landscape: Identifying and Interpreting Africanisms." National Center for Cultural Resources, US. Department of the Interior National Park Service. 2003.

Olaniyi, Rasheed. "Approaching the Study of Yorùbá Diaspora in Northern Nigeria in $20^{\text {th }}$ Century." IFRA Special Research Issue. 2, (2013): 67-89.

Ladele, T.A.A. Àkójọpọ İwádí İjìnle Àșà Yorùbá. Ibadan (Nigeria): Macmillan Press. 1986.

Toyin Falola. and Matt D. Childs. The Yorùbá Diaspora in the Atlantic World. Bloomington: Indiana University Press, 2004.

Raji, O.W. and Rasaq Atanda Ajadi. "A Stylistic Analysis of Ekun Iyawo." Research on Humanities and Social Sciences. 3.9, (2013): 33-51.

Winant, Howard. "Race and Race Theory." Annual Review of Sociology. 26 (2000): 1-21.

Woodson, Carter G. The Miseducation of the Negro. New York: Dover Publications, Inc. 1933. 